\title{
The Horse Before the Cart! The English Language Learners Experience of Using E-Learning System.
}

\author{
http://dx.doi.org/10.3991/ijet.v7i2.1962 \\ Mohammad Madallh Alhabahba ${ }^{1}$, Azidah Abu Ziden ${ }^{2}$, Ali Abbaas Albdour ${ }^{3}$, Bashar Taha Alsayyed ${ }^{1}$ \\ ${ }^{1}$ Taibah University, Saudi Arabia \\ ${ }^{2}$ University Sains Malaysia, Penang, Malaysia \\ ${ }^{3}$ Princess Nora Bint Abdul Rahman University, Saudi Arabia
}

\begin{abstract}
This study examined the intention to use Elearning among EFL learners. A total of 147 English language learners responded to the survey, these students have access to E-learning system. The chief purpose of this paper aims to understand the factors that affect the students' intention to use E-learning in Malaysian context. The findings of the study revealed that that perceived ease of use and perceived usefulness were able to be significant determinants of intention to use. Based on factor analysis, cognitive attitude and affective attitude were added to the modified framework as potential mediating factors. Moreover, cognitive attitude is fully mediating the relationship between perceived ease of use, perceived usefulness, and intention to use. Meanwhile, the study results indicated that the cognitive attitude is a significant determinant of intention to use. The study helps to understand the significant factors to explain, predicate and measure the acceptance of E-learning as a new tool ofstudents learning process.
\end{abstract}

Index Terms-Cognitive attitude, affective attitude, Technology Acceptance Model, E-learning, English language learners.

\section{INTRODUCTION}

The power of information and its adoption in most of the educational organizations have been a critical debate of governments' educational policies. However, the lack of studies in E-learning and the factors that affect it, have been a major issue among researchers [1]. The impact growing of E-learning field among educational bodies, especially in a developing country like Malaysia, call for more research in the field of E-learning implementation process. This emphasis brings solutions that enhances knowledge and performance to both learners as well as educational institutions [1]. Many studies along with educational organizations call for more attention to be drawn to implement E-learning programs. In addition, serious investments by educational bodies are made to implement E-learning programs. Klaus et al., argued that "There are many organizations that spend a large portion of their budget on information technology to improve students' performance or overall organizational performance" [2]. References [3, 4]pointed out that adoption of such a system could be profitable, minimize the costs, improve the growing of the institution and more importantly provide quality education to these educational bodies. Empirical studies acknowledged that necessary skills and knowledge can be acquired throughout E- learning, and it helps to pave the way to learners, participants and instructors to gain them [5-7]. Researchers indicated that the use of online learning enhance students' knowledge, performance and the quality of education [811]. It is important to note that acquiring new technology skills will extend learning environment in the educational organization which influenced by students perception, behavioural intention and attitude toward a new system [12]. This study aims to answer the call of more focus to drawn upon the adoption of E-learning as new teaching and learning approach. However, there are number of factors (e.g. perceived ease of use and usefulness) contribute to the adoption E-learning system. Therefore, this study will try to underline the factors that affect students' intention to use E-learning system.

\section{A. E-learning as new learning tool}

The importance of adoption of new teaching approaches, that could be more effective, rather than traditional on-campus approaches has gained greater interests recently [13-15]. Many studies have been carried out and intensified the importance of studying several factors that affect the intention to use E-learning [16-18]. Furthermore, the shifting phase from traditional learning style into web- based style has resulted into more emphasis on E-learning as a new style for delivering course content [19]. Teachers' role has been investigated mainly on Elearning literature [20] and what teachers can do or have they done while the students' attitudes remains largely undocumented [21]. Many studies call for the importance of implementing E-learning as a tool of interaction between the instructors and students, in which to what extent they find the E-learning useful [22].

At the macro level, many developing countries are moving toward becoming productive ones in terms of knowledge and services, yet more attention should be done in these areas $[23,24]$. Because the primary key for these countries is to play an active role into becoming knowledgeable society seeking new aptitudes, it is important to investigate the factors that enhance education field that utilizes E-learning system as a method of education [23]. Therefore, such development is needed due to raising demands of moving from traditional learning style into more active learning style. Pursuant to this development over the past years the impact of using E-learning into the educational organizations played an important role in effective learning, students have the chance to 
interact with teachers, course content, and their peers as well [25].

\section{B. Education and Technology}

The use of the internet as a basic tool in delivering lessons saved time and cost to many educational organizations [26]. Therefore, it presents a new paradigm for education, which results into rapid growth in both sectors as a mean of training and education [27, 28]. E-learning allows learners to communicate easily with each other regardless their geographical or time differences [29]. The use of technology in education has also offered support to teachers in order to deliver even better understanding of content materials to the students, because it is an alternative way of traditional learning [28]. Educational organizations have adopted E-learning as an impact tool of learning [11]. Accordingly, students are offered to attend their classes, interact with teachers and peers to do their assignments on a distance way [28]. Students then have the chance to promote this learning through interaction by face-to-face experience [27]. Moreover, it helps in solving accessibility of education, cost, constraints of time and place [20]. One of the most important reasons to justify the use of technology in educational organizations, according to [20], is to improve education quality as well as minimize the cost. Reference [20] found that educational organizations have spent over $24 \%$ on E-learning initiatives in 2001 and the percentage is expected to grow more. On the other hand, motivation to use the internet among both learners and teachers has been significantly affected both learning and teaching process because of successful implementation of E-learning [30]. However, there are still many concerns on understanding why learners as well as teachers accept or reject information technology like students' attitudes of E-learning usefulness, added value or the difficulties that they face when using such a new technology [31].

\section{THEORETICAL BACKGROUND}

\section{A. Technology Acceptance Model(TAM)}

Technology Acceptance Model (TAM) is used to investigate how users' acceptance and usage placed upon the introducing of a new technology. The theory introduces two constructs perceived usefulness, perceived ease of use. TAM introduced perceived usefulness and perceived ease of use as having a considerable effect on users' attitude toward using a new technology. The model suggests when users' use or accept the technology, there are variables that influence their decisions, whether they how or when will they reject or accept this new technology [31]. In investigating the factors that affect the acceptance of technology, there are several models to achieve what should be investigated e.g. Theory of Reasoned Action (TRA) [32], Theory of Planned Behaviour (TPB) [33]. TAM is a developed model of TRA [32, 34]. The current research is established on Technology Acceptance Model [31] to measure, predict and explain user acceptance of E-learning system among English language learners. Furthermore, Technology Acceptance Model was established on TRA as theoretical foundation for identifying the causal associations among its variables. Therefore, TAM is very much considered less general than Theory of Reasoned Action. However, TAM is specifically assigned for studying technology usage [31].

\section{B. Reseach Theoretical model}

\section{1) Intention to use}

A considerable research field has recognized intention to use in terms of the usage, which can predict embryonic use of a new technology [35-39]. Reference [39]asserted that attitude to both behavioural intentions, and overt behaviour has been a major concern to research as well as theories.

Intention to use has been explored in many previous studies which indicate that the use of information technology is a key dependent variable in IS research. In addition, the intention to use is a valid predictor of actual use of IT $[11,40]$. Reference [41]reported that there is a link between both intention to use and actual use of information technology in which intention to use is the best predictor of actual behaviour. Reference[31] argued that users' use of information technology could be predicted practically well from users' intention to use information technology. He stated that intention to use influences any factors that affect the use of information technology in an indirectly way.Reference[35]found out that intention to use information technology has a direct effect on the use of information technology. Reference [39] argued that intention to use is guiding human behaviour. Thus, the intention to use is the primary antecedent of actual use [39].

\section{2) Attitude (cognitive, affective)}

Substantial body of research investigating the attitude in E-learning has established a base for defining the concept and the effect that has on E-learning[1, 39, 42]. The importance of attitude has emerged regardless the system advancement, but the effective implementation of this system may be affected by the users' attitude. Therefore, the greater individuals have positive attitude the more successful implementation of systems [1]. Reference [43] provided a wide-range of overview of attitude definition "Attitude toward behaviour is defined as a person's favourable/unfavourable evaluation of the behaviour in question". According to [31] attitude has formed the interest of the individual in which an individual is reaching a level of interest when using a specific information system. Inevitably, this level of interest affects the intention to use and actual use of a specific system [31, 43].

Reference [44]assessed the attitude in the field of Elearning; he found out that the positive attitudes found to affect the E-learning could be a major factor in affecting the integration as well as the use of the E-learning system in educational bodies. Reference [40]inspected the attitude factor, they found that perceived usefulness and perceived ease of use have positively affected attitude towards the intention to use those systems. A study conducted by [45]addressing attitude factor concludes that intention to use factor is positively affected by attitude factor. However, the use of information systems can place a difficulty issue because of the changing individuals' attitude [45, 46]. On the other hand, Yang et al. asserted that attitude should be divided into two socio-psychological constructs namely: affective and cognitive[47].

\section{3) Perceived usefulness}

Reference [12]defined perceived usefulness as "the degree of which a person believes that using a particular system would enhance his or her job performance". Moreover, reference [48]defined perceived usefulness as "the prospective adopter's subjective probability that 
applying the new technology from foreign sources will be beneficial to his personal and/or the adopting company's well-being" [48]. Reference [31] found that perceived usefulness has a positive effect on intention to use.

\section{4) Perceived ease of use}

Perceived ease of use defined as "the degree of which a person believes that using a particular system would be free of effort" [12]. Perceived ease of use is predictable to affect directly or indirectly intention to use [41, 49]. Reference [48] explained perceived ease of use as "the degree to which the prospective adopter expects the new technology adopted from a foreign company to be free of effort regarding its transfer and utilization". Moreover, reference [31]stated that perceived ease of use describes users' beliefs in which the total of demanding effort desired to use the system or the beliefs would explain and predicate the benefits of using a system.

Based on related literature review, Figure 1 shows the theoretical framework, proposed to describe and explain the relationship between perceived of use, perceived of value, attitude toward E-learning and Intention to use Elearning. Control variables of this study are gender, age, educational level, and time spent on the internet. The independent variables are perceived ease of use and perceived of usefulness. The mediating variable is attitude. The dependent variable is the intention to use Elearning. Actual use has been excluding from the study framework due to the fact that E-learning is a newly established system in the context of the study.

Based on the theoretical framework in figure 1, specific hypotheses were formulated in order to examine the relationship between perceived ease of use, perceived of usefulness and intention to use e-learning. Furthermore, the mediation role of attitude on the relationship between independent variables (perceived usefulness and perceived of ease of use) and the dependent variable (Intention to use e-learning) will be tested:

H1: There is a significant positive relationship between perceived usefulness and students' attitude toward using E-learning.

H2: There is a significant positive relationship between perceived ease of use and students' attitude toward using E-learning.

H3: There is a significant positive relationship between perceived usefulness and students' intention to use Elearning.

H4: There is a significant positive relationship between perceived ease of use and students' intention to use Elearning.

H5: There is a significant positive relationship between students' attitude to use E-learning and students' intention to use E-learning.

H6: The relationship between the independent variables (perceived ease of use, perceived usefulness) and the dependent variable (intention to use E-learning) is mediated by attitude.

\section{ReSEARCH Methodology}

The nature of this study is to support the proposed conceptual model as well as proposed hypotheses. The research design is a quantitative (non-experimental) in

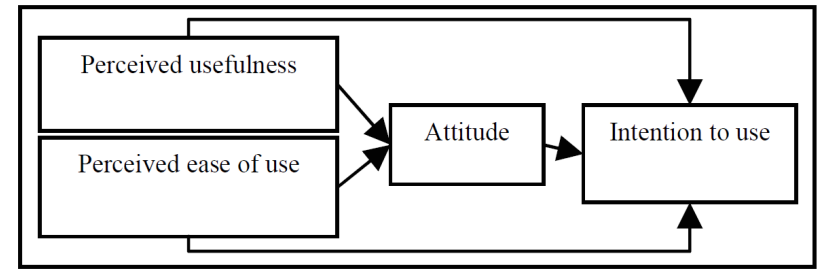

Figure 1. Theoretical framework

nature. This method expedites comparability and statistical accumulation of the data $[50,51]$. Moreover, the quantitative method helps in increasing the objectivity of interpreted data, validity, and reliability in which it helps to inspect the data in order to be presented in a way that is easily assignable to others [52]. A total of 147 questionnaire obtained from the targeted population were entered to SPSS v19. for further analysis.

\section{A. Instrumentation}

The items chosen to measure the operationalized variable were adopted from previous studies in order to fit the context of the study $[31,53]$. Therefore, a 5 point Likertscale is used to measure the study variables. The questionnaire is segmented into 5 parts (see table 1). Part 1, comprising 5 questions, addressing the participants' demographic variables (gender, age, race, time spent on the internet and educational level). Part 2, comprising perceived ease of use, including 4 statements. Part 3 is concerned with the perceived usefulness includes 4 statements. Section 4 includes Attitude, which indicates 4 questions. Section 5; concerns intention to use: this section includes 3 questions. Table 1 provides information about the items of each variable under the study and the source of the variables. Sections 2,3,4, and 5 were adapted from $[31,53]$. The following sections provides an expansive overview of data analysis and collection methods utilized in this study.

TABLE I.

QUESTIONNAIRE BREAKDOWN

\begin{tabular}{clcc} 
Section Component No. items & & $\begin{array}{c}\text { Items } \\
\text { sources }\end{array}$ \\
\hline \hline $\mathbf{1}$ & $\quad$ Background information & & \\
& $\begin{array}{l}\text { a. Race } \\
\text { b. Age }\end{array}$ & 4 & \\
& $\begin{array}{l}\text { c. Gender } \\
\text { d. time spent on internet }\end{array}$ & 4 & \\
& e. educational level & 4 & \\
& & & \\
\hline \hline $\mathbf{2}$ & Perceived of ease of use & 4 & (Davis et al., \\
& (PEOU) & & 1989; \\
$\mathbf{3}$ & Perceived usefulness (PU) & 4 & Masrom, \\
$\mathbf{4}$ & Attitude (ATT) & 4 & 2007) \\
$\mathbf{5}$ & intention to use (ITU) & 3 & \\
&
\end{tabular}

\section{1) Data analysis}

\section{a) Goodness of measures}

Factor analysis was utilized to accomplish data reduction or maintains the quality and characteristics of the primary items, and to skip the items that identified to have lower factor loading as well as cross loading [54]. Perceived ease of use and perceived of usefulness factor analysis indicated that the measurement used for perceived usefulness and perceived ease of use was valid. The first factor was the perceived usefulness; the second 
was perceived ease of use, with total variance of $78.754 \%$ and eigenvalues of 2.409 and 2.316 respectively, see table II.

In addition, table 3 . indicates the factor analysis results of intention to use which shows one factor solution. The Bartlett test of Sphericity was significant $\left(=242.063^{* * *}, \mathrm{p}\right.$ $<0.01)$ and the Kaiser-Meyer-Olkin measure of the sampling adequacy was greater than .50 , which was (0.747).

The results in table 4 show two factor solutions. The first factor was the affective attitude and the second factor was cognitive attitude with eigenvalues of 1.669 and 1.468 respectively and total variance of $78.439 \%$ percent. KMO measure of sampling adequacy was .547 showing inter-correlations while the Bartlett's Test of Sphericity was $\left(128.440^{* * *}, \mathrm{p}<0.01\right)$. The results of the factor analysis earlier revealed that the measurement employed for attitude factors was valid. In a line with Yang et al. (2004) findings the results of the study revealed that attitude should be divide into two separate sociopsychological constructs ( affective and cognitive), which is on contrary to Davis (1989) who stated that attitude adds little value in understanding the acceptance of technology. A complete of three factor analyses was executed for the variables under the study (i.e. perceived ease of use and perceived usefulness, attitude, and intention to use).

The consistency and the internal validity of the items that have been employed in this research were examined by reliability analysis [50]. In addition, the reliability of the instruments' Cronbach Alpha less than .5 is not acceptable [55]. Table 4 indicates that the Cronbach's alpha reliability overall scale of each of the factors ranged from .63 to .887 , which is contemplated acceptable scores [56] and none of the items was deleted for further analysis. It can be concluded that the reliability analysis results revealed that the questionnaire is a reliable measurement instrument. Based on factor analysis of attitude variable, two dimensions have been added to the study. Consequently, the framework of the study has been modified in order to reflect the attitude variable.

TABLE II.

FACTORS LOADINGS OF PERCEIVED USEFULNESS AND PERCEIVED EASE OF USE

\begin{tabular}{lcc}
\multicolumn{1}{c}{1} & 2 \\
\hline \hline Factor 1: Perceived Usefulness (PU) & \\
PU3 & .900 & .170 \\
PU2 & .868 & .283 \\
PU1 & .821 & .278 \\
\hline \hline Factor 2: Perceived Ease of Use (PEOU) \\
PEOU2 \\
PEOU1 \\
PEOU3 \\
Eigenvalue & .188 & .863 \\
Variance $(\%)$ & .233 & .847 \\
Total variance & 2.409 & 2.316 \\
& 40.157 & 38.598 \\
& \multicolumn{2}{c}{78.754}
\end{tabular}

TABLE III.

FACTOR LOADINGS OF INTENTION TO USE.

Factor 4: 1

\begin{tabular}{cc}
\hline \hline ITU3 & .908 \\
ITU2 & .903 \\
ITU1 & .898 \\
\hline \hline Eigenvalue & 2.447 \\
Variance $(\%)$ & 81.566 \\
Total variance & 81.566
\end{tabular}

TABLE IV. FACTOR LOADINGS OF ATTITUDE (AFFECTIVE, COGNITIVE)

\begin{tabular}{lll} 
& 1 & 2 \\
\hline \hline Factor: affective & \\
ATT1 & .911 \\
ATT4 & .904 \\
\hline \hline
\end{tabular}

\begin{tabular}{lcc}
\hline \hline Factor: cognitive & \\
ATT3 & & .861 \\
ATT2 & 1.669 & .840 \\
\hline \hline Eigenvalues & 41.730 & 1.468 \\
Variance $(\%)$ & 78.439 & \\
Total variance & &
\end{tabular}

TABLE V

CRONBACH'S ALPHA RELIABILITY TEST FOR THE VARIABLES UNDER THE STUDY

Variable

Cronbach's alpha

\begin{tabular}{cc}
\hline \hline Perceived Usefulness & .847 \\
Perceived Ease of Use & .879 \\
\hline Cognitive & .634 \\
Affective & .80 \\
Intention to Use & .887
\end{tabular}

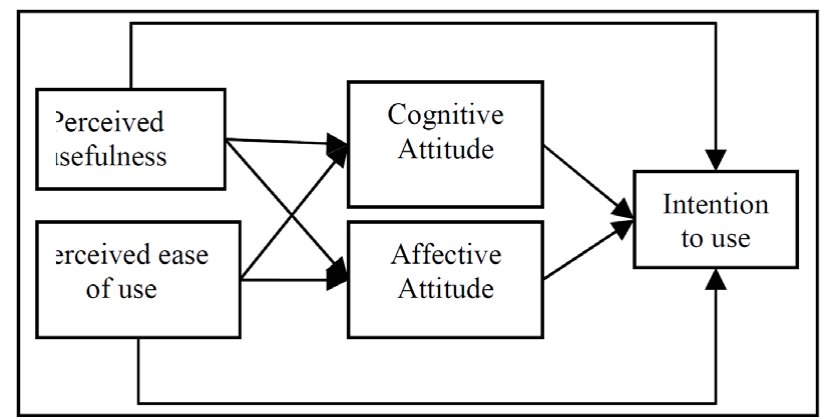

Figure 2. Modified Study Framework

Therefore, based on the changes that occur in the framework, the original hypotheses related to the relationship between attitude and the other variables of the study have been restated. The hypotheses that have been restated will reflect the addition of the new two dimensions of attitude as well as the hypothesized relationships between attitude and the other variables of under the study. The following section shows the restated hypotheses:

H1.a: there is a significant positive relationship between perceived usefulness and affective attitude.

H1.b: there is a significant positive relationship between perceived usefulness and cognitive attitude.

H2.a: there is a significant positive relationship between perceived ease of use and cognitive attitude. 
H2.b:there is a significant positive relationship between perceived usefulness and affective attitude.

H5: There is a significant positive relationship between students' attitude (cognitive and affective attitude) and intention to use E-learning

H5.a: There is a significant positive relationship between students' cognitive attitude and intention to use Elearning.

H5.b: There is a significant positive relationship between students' affective attitude and intention to use Elearning.

H6: The relationship between the independent variables (perceived ease of use, perceived usefulness) and the dependent variable (intention to use E-learning) is mediated by cognitive attitude.

H6.a: The relationship between perceived ease of use and intention to use is mediated by cognitive attitude.

H6.b: The relationship between perceived usefulness and intention to use is mediated by cognitive attitude.

\section{FINDINGS}

\section{A. Respondents' Profile}

Section one in the questionnaire was utilized to establish respondents profile. Respondents were 147 English language learners. Of these, $45.6 \%$ were Malay students, $15.0 \%$ Indian students, $25.2 \%$ Chinese students and $14.3 \%$ were other students. Males constitute $22.4 \%$ and females constitute $77.6 \%$. In addition, $17.0 \%$ were grouped between $19-21$ years, $61.9 \%$ between $22-24$ years, $6.8 \%$ between $25-27$ years, $14.3 \%$ of respondents were grouped 28 years old or more. More than half of the respondents, $57.1 \%$, were spending time on internet of more than 7 hours per week, $24.5 \%$ were spending time on internet between 4 to 6 hours per week and 18.4\% were spending time on internet between 1 to 3 hours per week. A total of 116 or $78.9 \%$ of the students were enrolled in degree level, 31 students were found to be enrolled in postgraduate level.

\section{B. Correlation Analysis}

Table 6 reveals correlations for all variables under the study. Perceived ease of use was positively significant correlated to perceived of usefulness $(\mathrm{r}=.520, \mathrm{p}<0.01)$, cognitive attitude $(\mathrm{r}=.383, \mathrm{p}<0.01)$, intention to use $(\mathrm{r}=$ $.391, \mathrm{p}<0.01)$ and insignificantly correlated to affective attitude $(\mathrm{r}=-.017, \mathrm{p}>0.05)$. Perceived of usefulness was positively significant correlated to cognitive attitude $(\mathrm{r}=.474, \mathrm{p}<0.01)$, intention to use $(\mathrm{r}=.508, \mathrm{p}<0.01)$, and insignificantly correlated to affective $(\mathrm{r}=-.073, \mathrm{p}>0.05)$. Cognitive attitude was negatively significant correlated to affective attitude $(\mathrm{r}=-.217, \mathrm{p}<0.01)$ and intention to use $(\mathrm{r}=.440, \mathrm{p}<0.01)$. Affective attitude was negatively significant correlated to intention to use $(\mathrm{r}=-.196, \mathrm{p}>0.05)$.

TABLE VI.

CORRELATIONS ANALYSIS

\begin{tabular}{cccccccc} 
& Mean & $\begin{array}{c}\text { Std. } \\
\text { Dev }\end{array}$ & PEoU & PU & Cognitive & Affective ITU \\
\hline \hline PEoU & 2.0227 & .68542 & 1 & & & & \\
PU & 2.2472 & .75458 & $.520^{* *}$ & 1 & & & \\
Cognitive & 2.0272 & .73741 & $.383^{* *}$ & $.474^{* *}$ & 1 & & \\
Affective & 2.9592 & 1.16969 & -.017 & -.073 & $-.217^{* *}$ & 1 & \\
ITU & 2.0023 & .76301 & $.391^{* *}$ & $.508^{* *}$ & $.440^{* *}$ & $-.196^{*}$ & 1 \\
\hline \hline
\end{tabular}

\section{Hypotheses Testing}

Multiple Regression Analysis (MRA) was employed to find out the relationships between the dependent and independent variables. The first MRA was employed to test Hypotheses 1.b and Hypothesis 2.a. The R square value indicated that $39.5 \%$ of variance in cognitive attitude can be explained by perceived usefulness and perceived ease of use $(\mathrm{R} 2=0.395 ; \mathrm{F}=45.972 ; \mathrm{p}<0.01)$. The regression results in Table 6 also showed that perceived usefulness $(\beta=0.434, p<0.01)$, perceived ease of use $(\beta=$ $.295, \mathrm{p}<0.01)$ are significant determinants for cognitive attitude. Thus, hypotheses H1.b and H2.a are supported. Derived on the beta values, perceived usefulness $(\beta=$ .434) seemed to have the strongest effect on cognitive attitude, followed by perceived ease of use $(\beta=.295)$ See Table VII.

The second MRA was conducted to test Hypothesis 1.a and Hypothesis 2.b. The $\mathrm{R}$ square value indicated that $0.6 \%$ of variance in affective attitude can be explained by perceived usefulness and perceived ease of use (R2 $=0.006 ; \mathrm{F}=.423 ; \mathrm{p}>0.05)$. The regression results in Table 7 also showed that perceived usefulness $(\beta=-.087, p>0.05)$, perceived ease of use $(\beta=0.028, p>0.05)$ are not significant determinants for affective attitude. Thus, hypotheses H1.a, H2.b are not supported (see Table VIII).

To determine the relationship between perceived usefulness and perceived ease of use and intention to use Elearning, a multiple regression analyses was performed. The $\mathrm{R}$ square value suggested that $34.3 \%$ of variance in intention to use can be explained by perceived usefulness and perceived ease of use $(\mathrm{R} 2=0.343 ; \mathrm{F}=36.862 ; \mathrm{p}<0.01)$. The regression results in Table 4.19 also showed that perceived usefulness $(\beta=0.444, p<.01)$, perceived ease of use $(\beta=0.219, \mathrm{p}<.01)$ are significant determinants for intention to use. Thus, hypotheses $\mathrm{H} 3$ and $\mathrm{H} 4$ are supported. Based on the beta values, perceived usefulness $(\beta$ $=0.444)$ appeared to have the strongest effect on intention to use, followed by perceived ease of use $(\beta=.219)$ (see Table IX).

A multiple regression analyses was performed to determine the relationship between cognitive attitude and affective attitude and intention to use E-learning. The $\mathrm{R}$ square value indicated that $32.3 \%$ of variance in intention to use can be explained by cognitive attitude and affective attitude $(\mathrm{R} 2=0.323 ; \mathrm{F}=33.616 ; \mathrm{p}<0.01)$. The regression results in Table 4.19 also showed that cognitive attitude $(\beta$ $=0.574, \mathrm{p}<0.01)$, is a significant determinant for intention to use, meanwhile affective attitude $(\beta=0.023, \mathrm{p}>0.05)$ is a not significant determinant for intention to use Elearning. Thus, hypotheses H5.a was supported, where as H5.b was not supported (see Table X).

Hypothesis H6.a and H6.b predicted that cognitive attitude mediates the relationship between perceive usefulness and perceive ease of use and intension to use Elearning. Table 10 provides the results of hierarchical regression analysis. The perceived usefulness and perceived ease of use were entered in the first step. The two independents variables were significant: perceive usefulness $(\beta=.449, p<0.01)$, perceived ease of use $(\beta=.170$, $\mathrm{p}<0.05$ ). In the second step, the mediator (cognitive attitude) was entered into the equation. The results of the second step indicated that perceived usefulness remained significant but its strength decreased $(\beta=.289, \mathrm{p}<0.01)$. In addition, the results showed that perceived ease of use was 
insignificant $(\beta=.057, \mathrm{p}>0.05)$. This suggests that perceived usefulness influences intension to use e-learning directly and indirectly through cognitive attitude (partial mediation) and perceived ease of use influences intension to use e-learning directly through cognitive attitude (full mediation). Hence, hypotheses H6.a and H6.b are supported (Table XI).

TABLE VII.

REGRESSION ANALYSIS OF PU, PEOU, AND COGNITIVE ATTITUDE.

\begin{tabular}{cccc}
$\begin{array}{c}\text { Independent } \\
\text { Variables (IV) }\end{array}$ & Beta & t-test & Sig \\
\hline \hline PEoU & $0.295^{* *}$ & 3.987 & 0.000 \\
PU & $0.434 * *$ & 5.856 & 0.000 \\
\hline \hline R2 & & 0.395 & \\
Adjusted R2 & & 0.386 & \\
Sig. F & & 0.000 &
\end{tabular}

TABLE VIII.

REGRESSION ANALYSIS OF PU, PEOU, AND AFFECTIVE ATTITUDE Model

\begin{tabular}{cccc} 
IV's & Beta & t-test & Sig \\
\hline \hline PEoU & .028 & .288 & .774 \\
PU & -.087 & -.895 & .372 \\
\hline \hline R2 & & .006 & \\
Adjusted R2 & & -.008 & \\
F Value & & .423 & \\
Sig. F & & .656 &
\end{tabular}

TABLE IX.

REGRESSION ANALYSIS OF PU, PEOU, AND INTENTION TO USE.

\begin{tabular}{cccc} 
IV's & $\begin{array}{c}\text { Model } \\
\text { Beta }\end{array}$ & t-test & Sig \\
\hline \hline PEoU_Mean & $.219^{* *}$ & 2.776 & .006 \\
PU_Mean & $.444^{* *}$ & 5.611 & .000 \\
\hline \hline R2 & & .343 & \\
Adjusted R2 & & .334 & \\
F Value & & 36.862 & \\
Sig. F & & .000 &
\end{tabular}

TABLE X

REGRESSION ANALYSIS OF COGNITIVE, AFFECTIVE,AND INTENTION TO USE.

\begin{tabular}{cccc}
\multicolumn{1}{c}{ IV's } & $\begin{array}{c}\text { Model } \\
\text { Beta }\end{array}$ & t-test & Sig \\
\hline \hline cognitive & $.574 * *$ & 8.002 & .000 \\
affective & .023 & .318 & .751 \\
\hline \hline R2 & \multicolumn{3}{c}{.323} \\
Adjusted R2 & .313 & \\
F Value & & 33.616 & \\
Sig. F & & .000 &
\end{tabular}

TABLE XI.

REGRESSION ANALYSIS OF COGNITIVE, PU, PEOU,AND INTENTION TO USE.

\begin{tabular}{ccccccc} 
Variable & \multicolumn{3}{c}{ Model 1 } & \multicolumn{3}{c}{ Model 2 } \\
\hline \hline & Beta & t-test & Sig & Beta & t-test & Sig \\
PEoU & $.170^{*}$ & 2.119 & .036 & .057 & .722 & .472 \\
PU & $.449^{* *}$ & 5.595 & .000 & $.289^{*}$ & 3.479 & .001 \\
Cognitive & & & & $.380^{* *}$ & 4.521 & .000 \\
\hline \hline R2 & & .303 & & & .392 & \\
Adjusted R2 & 293 & & & 379 & \\
F Value & & 30.397 & & & .000 & \\
Sig. F & & .000 & & & .000 &
\end{tabular}

V. DISCUSSION

A. The Relationship between Perceived Ease of Use, Perceived Usefulness, Cognitive and Affective Attitude.

A possible explanation of this finding is that students viewed E-learning system as valuable and useful tool in learning consisting valuable and useful information that help them in their course work, which affect students' cognitive attitude. On the contrary, perceived usefulness and perceived ease of use are not significant determinants of affective attitude. Therefore, this study's finding is consistent with the findings of [47]. Generally, if students were perceived E-learning as useful tool and easy to use, the likelihood of attitude to be viewed as favourable learning tool. Given thatreference[31] finding about attitude, in which it attaches little value in describing IS usage, the full understanding of attitude construct in IS research has often been neglected in explaining technology acceptance. A possible explanation of the relationship between perceived usefulness and ease of use on affective attitude is that students viewed E-learning system as dreadfully formed interfaces or complex producers to be used that may contribute to students' dissatisfaction with E-learning system. Furthermore, students may affect each other in terms of affective attitude. Students seemed to develop evaluative beliefs in regard to E-learning system in which they affect each other.

\section{B. The Relationship between Perceived Ease of Use, Perceived Usefulness and intension to use}

The findings of this study concur with the findings of previous researchers [12, 57-61]. The findings of the study revealed that perceived usefulness has the strongest effect on intention to use, which considered as an important factor influences user technology acceptance [31, 47, 58, $62,63]$. The results show that students seem to see the usefulness of E-learning more important to them than perceived ease of use. A possible explanation is that students did not receive sufficient training to use the Elearning website, thus students are facing awkwardness in using E-learning website. Therefore, related training to use E-learning website would save the time that the students spend in order to know how to use the website.

\section{The Relationship between Cognitive Attitude, Affective Attitude and Intension to Use.}

The result of the study is in a line with $[64,65]$ who found out that cognitive has an influence on intention to use. The second result is in line with [66]findings who found out that affective attitude is not a major significant determinant for intention to use[66]. A possible explanation for the first result is that English language learners form their evaluative beliefs about the system, these beliefs (i.e., the cognitive attitude) were developed into learners' cognitive needs that found in E-learning system, which affect their intention to use E-learning. Whereas the second result could be explained as English language learners tend to prefer to attend classes in order to answer their inquiries immediately and to engage into face-to-face interaction, which the website lacks of such an interaction. This preference affects their affective attitude, which in turn affects their intention to use E-learning. 


\section{The Mediation Role of Cognitive Attitude on the Relationship between the Independent Variables and the Dependent variable}

The first result was the mediation role of cognitive attitude between perceived ease of use and intention to use the result of the study indicated that cognitive attitude was fully mediated the relationship. In addition, the second result revealed that the mediation role of cognitive attitude between perceived usefulness and intention to use was partial mediated the relationship. These results are corresponding to [47]findings who found that the cognitive dimension has a significant mediation role between perceived ease of use, perceived usefulness and intention to use technology. Reference [47]results revealed that affective attitude has no significant mediation role. A possible explanation of the affective attitude finding is that affective attitude is preferably to be introduced as dependent variable rather than a mediator. Another possible explanation of this result is that students hold positive cognitive awareness of the importance of E-learning, when E-learning is regarded by students as useful tool i.e. perceived usefulness, students will tend to use E-learning. In addition, their capability, education, and experience influence their attitude, thus their cognitive attitude in turn will affect their intention to use E-learning. A possible explanation of the second result is that attitude in nature is contagious and as students engage together with their work or assignment, they tend to express their own attitudes as well as they listen to each other attitude in which they may influence each other about E-learning, which in turn affect the way they intended to use E-learning.

\section{CONCLUSION AND IMPLICATIONS}

The findings of the study confirmed that English language learners' cognitive attitude influence the acceptance of technology. Specifically, the results revealed that supporting English language learners' cognitive attitude to the E-learning system could significantly ameliorate English language learners' acceptance E-learning system. Therefore, English language lecturers and administrators have the chance to improve English language learners' throughout affecting English language learners' cognitive attitude. In addition, the value of E-learning system underscored by English language learners' beliefs as well as their training to put forward the acceptance of Elearning system.

Additionally, their interaction with others is also underscored by their attitude toward the E-learning system. It should be noted that negative attitude works against the aim of introducing E-learning system, should then a sufficient encouragement placed upon students replace aversion and anxiety in order to embrace E-learning successfully. Easy designed and useful interfaces will increase the students' attitude to use E-learning, designers of the website should consider the interfaces of E-learning system to ensure that students logged in easily and find it useful to use.

The study results indicated that English language learners' perceived usefulness and affective attitude is not supported. Therefore, it should be noted that English language learners should perceive E-learning system as a useful tool. Again, encouraging English language learners to use E-learning and enlighten them with the fact that using E-learning makes their learning process more effective and conquer higher performance. In addition, when English language learners are satisfied with using Elearning, the likelihood to use E-learning system is higher. The satisfaction of English language learners can be achieved throughout two dimensions; the first is the interaction with the instructors, while the second is the interaction with other peers. The satisfaction level would then increase English language learners confidence to use E-learning.

English language instructors as well as administrators should consider the needs and values of English language learners in order to ensure that E-learning is effectively addressing their desires and demands. Therefore, enhancing E-learning system would affect the English language learners' intention to use E-learning. This can be achieved by the attractive design of E-learning as well as the effective content learning materials that attract English language learners.

\section{REFERENCES}

[1] Liaw, S.S., H.M. Huang, and G.D. Chen, Surveying instructor and learner attitudes toward e-learning. Computers \& Education, 2007. 49(4): p. 1066-1080. http://dx.doi.org/10.1016/j.comped u.2006.01.001

[2] Klaus, T., T. Gyires, and H.J. Wen, The use of web-based information systems for non-work activities: an empirical study. Human Systems Management, 2003. 22(3): p. 105-114.

[3] Schroeder, R., Blogging online learning news and research. Journal of Asynchronous Learning Networks, 2003. 7(2): p. 5660.

[4] Valenta, A., et al., Identifying student attitudes and learning styles in distance education. Journal of Asynchronous Learning Networks, 2001. 5(2): p. 111-127.

[5] Tzouveli, P., P. Mylonas, and S. Kollias, An intelligent e-learning system based on learner profiling and learning resources adaptation. Computers \& Education, 2008. 51(1): p. 224-238. http://dx.doi.org/10.1016/j.compedu.2007.05.005

[6] Dagger, D., V. Wade, and O. Conlan. Towards "anytime, anywhere "learning: The role and realization of dynamic terminal personalization in adaptive elearning. in World Conference on Educational Multimedia. 2003. Hawaii: Hypermedia \& Telecommunications.

[7] Karpouzis, K., et al., Educational resources and implementation of a Greek sign language synthesis architecture. Computers \& Education, 2007. 49(1): p. 54-74. http://dx.doi.org/10.1016/j.com pedu.2005.06.004

[8] Nguyen, D.M. and G. Kulm, Using web-based practice to enhance mathematics learning and achievement. Journal of Interactive Online Learning, 2005. 3(3): p. 1-16.

[9] Ming, T. and L. Bidmeshki, Evaluating Malaysian science and technology undergraduates' reactions towards an online ESP course. CALL-EJ online, 2006. 7(2): p. 7-2.

[10] Kadijevich, D. and L. Haapasalo, Factors that influence student teacher's interest to achieve educational technology standards. Computers \& Education, 2008. 50(1): p. 262-270. http://dx.doi.org/10.1016/j.compedu.2006.05.005

[11] Sun, H. An integrative analysis of TAM: Toward a deeper understanding of technology acceptance model. in the Americas Conference on Information Systems (AMCIS) '03. 2003. Tampa, FL.

[12] Davis, F.D., Perceived usefulness, perceived ease of use, and user acceptance of information technology. MIS quarterly, 1989:a. 13(3): p. 319-340.

[13] Frager, A.M., Video Technology and Teacher Training: A Research Perspective. Educational Technology, 1985. 25(7): p. 20-22.

[14] Jones, C.S. and W.M. Timpson, Technologically mediated staff development: A retrospective case study. American Journal of Distance Education, 1991. 5(1): p. 51-56. http://dx.doi.org/10.1 080/08923649109526732 
[15] Maloy, W.L. and N.N. Perry, A Navy video teletraining project: Lessons learned. American Journal of Distance Education, 1991. 5(3): p. 40-50. http://dx.doi.org/10.1080/08923649109526762

[16] Dohner, C.W., et al., Teaching basic science and clinical medicine at a distance: An evaluation of satellite communication. Distance Education, 1985. 6(1): p. 4-33. http://dx.doi.org/10.1080/ 0158791850060101

[17] Sanders Lopez, E. and E. Nagelhout, Building a model for distance collaboration in the computer-assisted business communication classroom. Business Communication Quarterly, 1995. 58(2): p. 15-22. http://dx.doi.org/10.1177/10805699950 5800203

[18] Saba, F., Research in distance education: A status report. The International Review of Research in Open and Distance Learning, 2000. 1(1): p. 1-9.

[19] Parson, R., An investigation into instruction. . 1997, University of Toronto. : Intario Institute for Studies in Edutation (OISE)

[20] Alexander, S., E-learning developments and experiences. Education \& Training, 2001. 43(4/5): p. 240-248. http://dx.doi.org/10.1108/00400910110399247

[21] Keller, C. and L. Cernerud, Students' perceptions of e-learning in university education. Journal of Educational Media, 2002. 27(1-2): p. 55-67. http://dx.doi.org/10.1080/0305498032000045458

[22] Landry, B.J.L., R. Griffeth, and S. Hartman, Measuring student perceptions of blackboard using the technology acceptance model. Decision Sciences Journal of Innovative Education, 2006. 4(1): p. 87-99. http://dx.doi.org/10.1111/j.1540-4609.2006.00103.x

[23] Andrade, J., et al., Guidelines for the development of e-learning systems by means of proactive questions. Computers \& Education, 2008. 51(4): p. 1510-1522. http://dx.doi.org/10.1016/j.compedu. 2008.02.002

[24] Welle-Strand, A. and T. Thune, E-learning policies, practices and challenges in two Norwegian organizations. Evaluation and program planning, 2003. 26(2): p. 185-192. http://dx.doi.org/ 10.1016/S0149-7189(03)00006-5

[25] Johnson, R.D., S. Hornik, and E. Salas, An empirical examination of factors contributing to the creation of successful e-learning environments. International Journal of Human-Computer Studies, 2008. 66(5): p. 356-369. http://dx.doi.org/10.1016/j.ijhcs.2007 .11 .003

[26] Monahan, T., G. McArdle, and M. Bertolotto, Virtual reality for collaborative e-learning. Computers \& Education, 2008. 50(4): p. 1339-1353. http://dx.doi.org/10.1016/j.compedu.2006.12.008

[27] El-Deghaidy, H. and A. Nouby, Effectiveness of a blended elearning cooperative approach in an Egyptian teacher education programme. Computers \& Education, 2008. 51(3): p. 988-1006. http://dx.doi.org/10.1016/j.compedu.2007.10.001

[28] Wu, J.H., et al., Analysis of E-learning innovation and core capability using a hypercube model. Computers in Human Behavior, 2008. 24(5): p. 1851-1866. http://dx.doi.org/10.1016/ j.chb.2008.02.008

[29] Kester, L., P. Kirschner, and G. Corbalan, Designing support to facilitate learning in powerful electronic learning environments. Computers in Human Behavior, 2007. 23(3): p. 1047-1054. http://dx.doi.org/10.1016/j.chb.2006.10.001

[30] Mahdizadeh, H., H. Biemans, and M. Mulder, Determining factors of the use of e-learning environments by university teachers. Computers \& Education, 2008. 51(1): p. 142-154. http://dx.doi.org/10.1016/j.compedu.2007.04.004

[31] Davis, F.D., R.P. Bagozzi, and P.R. Warshaw, User acceptance of computer technology: a comparison of two theoretical models. Management science, 1989:b. 35(8): p. 982-1003.

[32] Ajzen, I. and M. Fishbein, Understanding attitudes and predicting social behavior. Vol. 278. 1980: Prentice-Hall.

[33] Ajzen, I., The theory of planned behavior. Organizational behavior and human decision processes, 1991. 50(2): p. 179-211. http://dx.doi.org/10.1016/0749-5978(91)90020-T

[34] Fishbein, M. and I. Ajzen, Belief, attitude, intention and behaviour: An introduction to theory and research. 1975: Addison-Wesley.

[35] Venkatesh, V., et al., User acceptance of information technology: Toward a unified view. MIS quarterly, 2003. 27(3): p. 425-478.
[36] Levy, Y. and K.E. Murphy. Toward a value framework for online learning systems. in International Conference on Systems Science (HICSS'02). 2002. Hawaii: IEEE.

[37] Selim, H.M., Critical success factors for e-learning acceptance: Confirmatory factor models. Computers \& Education, 2007. 49(2): $\quad$ p. 396-413. http://dx.doi.org/10.1016/j.compedu.2005.09.004

[38] Ngai, E., J. Poon, and Y. Chan, Empirical examination of the adoption of WebCT using TAM. Computers \& Education, 2007. 48(2): p. 250-267. http://dx.doi.org/10.1016/j.compedu.2004.11. 007

[39] Ajzen, I., Nature and operation of attitudes. Annual review of psychology, 2001. 52(1): p. 27-58. http://dx.doi.org/10.1146/ annurev.psych.52.1.27

[40] Premkumar, G. and A. Bhattacherjee, Explaining information technology usage: A test of competing models. Omega, 2008 36(1): p. 64-75. http://dx.doi.org/10.1016/j.omega.2005.12.002

[41] Greer, T.H. and M.B. Murtaza, Web personalization: the impact of perceived innovation characteristics on the intention to use personalization. Journal of Computer Information Systems, 2003. 43(3): p. 50-55.

[42] Bhattacherjee, A. and G. Premkumar, Understanding changes in belief and attitude toward information technology usage: A theoretical model and longitudinal test. MIS quarterly, 2004. 28(2): p. 229-254.

[43] Venkatesh, V. and S.A. Brown, A longitudinal investigation of personal computers in homes: Adoption determinants and emerging challenges. MIS quarterly, 2001. 25(1): p. 71-102. http://dx.doi.org/10.2307/3250959

[44] Sam, H.K., A.E.A. Othman, and Z.S. Nordin, Computer selfefficacy, computer anxiety, and attitudes toward the Internet: A study among undergraduates in Unimas. Journal of Educational Technology and Society, 2005. 8(4): p. 205-219.

[45] Shih, H.P., Using a cognition-motivation-control view to assess the adoption intention for Web-based learning. Computers \& Education, 2008. 50(1): p. 327-337. http://dx.doi.org/10.1016 /j.compedu.2006.06.001

[46] Petty, R.E. and J.A. Krosnick, Attitude strength: Antecedents and consequences. 1995: Lawrence Erlbaum Associates, Inc.

[47] Yang, H. and Y. Yoo, It's all about attitude: revisiting the technology acceptance model. Decision Support Systems, 2004 38(1): p. 19-31. http://dx.doi.org/10.1016/S0167-9236(03)00062-9

[48] Phillips, L.A., R. Calantone, and M.T. Lee, International technology adoption: Behavior structure, demand certainty and culture. Journal of Business \& Industrial Marketing, 1994. 9(2): p. 16-28. http://dx.doi.org/10.1108/08858629410059762

[49] Ong, C.S. and J.Y. Lai, Gender differences in perceptions and relationships among dominants of e-learning acceptance. Computers in Human Behavior, 2006. 22(5): p. 816-829. http://dx.doi.org/10.1016/j.chb.2004.03.006

[50] Sekaran, U., Research Methods for Business: A Skill Building Approach. 2003: New Delhi: John Wiley and Son Inc.

[51] Sekaran, U., Research methods for business: A skill building approach. 2006: Wiley-India.

[52] Byrne, D., Interpreting quantitative data. 2002: Sage Publications Ltd.

[53] Masrom, M., Technology acceptance model and E-learning, in 12th International Conference on Education. 2007: Sultan Hassanal Bolkiah Institute of Education, Brunei Darussalam. p. 21-24.

[54] Hair, J., et al., Multivariate Data Analysis. 2006: New Jersey: Prentice-Hall.

[55] Ramayah, T., The role of voluntariness in distance education students' usage of a course website. Turkish online Journal of Distance Education, 2010. 9(3): p. 96-105.

[56] Nunnally, J.C., Psychometric theory. 1967: Tata McGraw-Hill Education.

[57] Taylor, S. and P.A. Todd, Understanding information technology usage: A test of competing models. Information systems research, 1995. 6(2): p. 144-176. http://dx.doi.org/10.1287/isre.6.2.144

[58] Chau, P.Y.K. and P.J.H. Hu, Information Technology Acceptance by Individual Professionals: A Model Comparison Approach*. 
Decision Sciences, 2001. 32(4): p. $699-719$ http://dx.doi.org/10.1111/j.1540-5915.2001.tb00978.x

[59] Featherman, M. Extending the technology acceptance model by inclusion of perceived risk. in the Seventh Americas Conference on Information Systems. 2001.

[60] Jantan, M., T. Ramayah, and W.W. Chin, Personal Computer acceptance by small and medium sized companies' evidence from Malaysia. Jurnal Manajemen \& Bisnes, 2001. 3(1): p. 1-14.

[61] Ndubisi, N.O., M. Jantan, and S. Richardson, Is the technology acceptance model valid for entrepreneurs? Model testing and examining usage determinants. Asian Academy of Management Journal, 2001. 6(2): p. 31-54.

[62] Subramanian, G.H., A Replication of Perceived Usefulness and Perceived Ease of Use Measurement. Decision Sciences, 1994. 25(5-6): p. 863-874. http://dx.doi.org/10.1111/j.1540-5915.1994 .tb01873.x

[63] Szajna, B., Empirical evaluation of the revised technology acceptance model. Management science, 1996. 42(1): p. 85-92. http://dx.doi.org/10.1287/mnsc.42.1.85

[64] Lavine C, J., On the Primacy of Affect in the Determination of Attitudes and Behavior: The Moderating Role of AffectiveCognitive Ambivalence. Journal of experimental social psychology, 1998. 34(4): p. 398-421. http://dx.doi.org/10.1006/ jesp.1998.1357

[65] Zajonc, R.B., On the primacy of affect. American psychologist, 1984. 39(2): p. 117-123. http://dx.doi.org/10.1037/0003-066X.39. $\underline{2.117}$

[66] Trafimow, D. and P. Sheeran, Some Tests of the Distinction between Cognitive and Affective Beliefs. Journal of experimental social psychology, 1998. 34(4): p. 378-397. http://dx.doi.org/ 10.1006/jesp. 1998.1356

\section{AUTHORS}

Mohammad Madallh Alhabahba is a lecturer at Taibah university, he received his Master in TESOL from University Sains Malaysia. His research interests are Creative writing, Research methodology, Curriculum \& Instructions, Teaching English to the Speakers of Other Languages (TESOL) and ICT, Internet and ELT; Online Professional Development; Reflective and Critical Practices; Teacher Development. he can be contacted at: mohd80ma@hotmail.com.

Dr. Azidah Abu Ziden is a Senior Lecturer in the School of Educational Studies, Universiti Sains Malaysia. Dr. Azidah is a PhD graduate from University of Canterbury, New Zealand and her expertise includes Instructional Design, e-learning and Educational Technology. At the moment her current research involves Learning Management System (LMS) in Education and Exploration of mobile learning in teaching and learning.

Dr. Ali Abbaas is an associate professor at College of Business and Administration Princess Nora Bint Abdul Rahman University. His research interests are human resource management, internal and external CSR.

Bashar Taha Alsayyed is a lecturer at Taibah university. He received his Master from Huddersfield university. His research interest at the moment is writing approaches of EFL learners.

Received 21 January 2012. Published as resubmitted by the authors 27 May 2012 